\title{
Tvrtko Vuković
}

tvrtkovukovic@yahoo.com

\section{Teološki nomadizam. Po/etika i politika zazorne sublimnosti u pjesništvu Delimira Rešickog ${ }^{1}$}

\begin{abstract}
Vuković Tvrtko, Teološki nomadizam. Po/etika i politika zazorne sublimnostiu pjesništvu Delimira Rešickog (Theological nomadism. Poet(h)ics and politics of the uncanny sublime in Delimir Rešicki's poetry). „Poznańskie Studia Slawistyczne” 1. Poznań 2011. Rys Press, pp. 275-289. ISSN 2084-3011.
\end{abstract}

The poetry written by the Croatian poet Delimir Rešicki is associated with some of the more influential concepts of the Romantic poets. The paper analyzes the method by which Rešicki develops Christlike motives as a model of shaping the authorial concept and comprehending the poetic identity associated with the idea of a (divine) Genius. The focus is therefore placed on two textual strategies: stylizing the lyrical subject as an urban model and representing the idea of nomadism as the predominant existential form. The phrase "theological nomadism" is hereby used to relate the convergence of Rešicki's lyrical poetry and Romanticism to some of the recent ethical and political debates in the field of theory.

Keywords: theological nomadism, the sublime, the uncanny, Christ, Romanticism, postmodernism, poetry.

1 U radu govorim o pjesništvu suvremenog hrvatskog pjesnika Delimira Rešickog. Rešicki je višestruko nagrađivan autor, uvrštavan je u sve utjecajne antologije i preglede hrvatskog pjesništva, a prevođen je na brojne strane jezike, između ostalih na engleski, njemački, francuski, talijanski i poljski. Pripadnik je naraštaja koji se u hrvatskoj književnosti javio osamdesetih godina dvadesetog stoljeća, a taj se naraštaj okupljao i oblikovao oko tada kultnog književnog časopisa „Quorum”. 
Već je tijekom osamdesetih godina dvadesetog stoljeća - točnije, nakon tiskanja knjige Sretne ulice (1987) koja je nagrađena tada vrlo utjecajnom omladinskom nagradom Sedam sekretara SKOJ-a - lirika Delimira Rešickog stekla u Hrvatskoj kultni status. To se ponajprije dogodilo zbog njezine povezanosti s popularnom kulturom, a u najvećoj mjeri s post-rock, post-punk svjetskom glazbenom scenom. Nick Cave and the Bad Seeds, Joy Division, Misfits samo su neki od bendova na čiju je glazbenu poetiku katkad izravno, a najčešće neizravno referirala autorova lirska poetika. (Dodajem kao napomenu da je Rešicki uređivao važan glazbeni časopis „Heroina nova” te je surađivao s alternativnom rock-grupom Roderick i bio članom alternativne rock-grupe Galebovi.) Kritika se, rekao bih s pravom, dosta iscrpno bavila tim vidom pjesništva Rešickog. Citate, aluzije ili parafraze djela popularne i rock-kulture analitičari su tumačili ili kao iskaz intertekstualne, intermedijalne i autoreferencijalne osviještenosti njegova pisma ili kao način da se prikaže poseban oblik izglobljenosti pojedinca u našem (postmodernističkom) svijetu gdje su sve vrijednosti obezvrijeđene, a egzistencija obestrašćena².

Sama lirika Rešickog, dakako ne gubeći iz vida prethodna čitanja, pruža mogućnost da joj se drukčije pristupi. Ona kao da se nudi da je se poveže s nekim utjecajnim koncepcijama romantičarske poetike. U raspravu je, u tom smislu, nužno uključiti teološki vid autorove lirike. Naime, od prve pjesničke zbirke Gnomi (1985) do posljednje Aritmija (2005) Rešicki ustrajno referira na kršćansku mitologiju. Mene, stoga, posebno zanima način na koji on razvija kristološke motive kao model oblikovanja koncepta autora, funkcije autorstva i u najširem smislu shvaćanja pjesničkog identiteta povezanog s idejom (božanskog) Genija. Pozornost, s tim u vezi, posvećujem dvjema tekstualnim strategijama: stilizaciji lirskog subjekta kao urbanog nomada i zastupanju ideje nomadizma kao prevladavajuće forme egzistencije. Te se strategije

2 O intermedijalnosti u pjesništvu Rešickog najopširnije je pisao Goran Rem (2003). O autoreferencijalnosti njegove lirike posljednji je pisao Pavao Pavličić (2008). $\mathrm{O}$ intertekstualnosti i intermedijalnosti te nekim vidovima postmodernističnosti autorova lirskog rukopisa pisao je Krešimir Bagić (2004). Sve ove teze uvažavao je i Vladimir Biti pri čitanju pjesme Mizar (2005). 
u lirici Rešickog, dakle, mogu razumjeti kao prevrednovanje, s jedne strane, romantičarske figure lutalice (eng. wanderer, franc. vagabond), a s druge, romantičarske ideje eskapizma.

Dužan sam, odmah na početku, pojasniti i sam naslov rada. Sintagmu „teološki nomadizam” preuzeo sam od hrvatskog evangeličkog teologa Borisa Gunjevića, točnije iz knjige Bog, na mukama, obrati apokalipse koju je objavio u koautorstvu s vrlo vjerojatno najutjecajnijim, a sigurno najpopularnijim filozofom današnjice Slavojem Žižekom. Sintagma „teološki nomadizam” služi mi da ovo približavanje lirske poetike Rešickog i romantizma povežem s nekim recentnim etičkim i političkim raspravama koje se vode na teorijskoj sceni ${ }^{3}$. U njima se mesijanska figura Isusa Krista najčešće dovodi u vezu s radikalnom lijevom, marksističkom, revolucionarnom mišlju. Ono što pritom koristim, kao jedno od interpretativnih uporišta, filozofsko-teološko-estetička je ideja sublimnog koja je, u većoj mjeri, oblikovana baš u vrijeme uspostave ili razvoja europskog romantizma ${ }^{4}$. Budući da je ta ideja u filozofiji, teologiji i estetici živahno obnovljena baš u našem postmodernističkom vremenu, preuzimam je kao sredstvo za čitanje oblika pale ili zazorne sublimnosti u lirici Rešickog. Pojmovi „sublimno” i ,zazorno” nisu samo dio jezika

3 Devedesetih godina dvadesetog stoljeća književna i kulturna teorija svoj je interes radikalno zaokrenula prema etici i politici. Na tragu Foucaultovih, Derridaovih, Lacanovih, Bourdieuovih, Althusserovih, Lévi-Straussovih radova, da spomenem samo neke istaknute francuske mislioce iz druge polovine dvadesetog stoljeća, nastaje cijeli niz teorijskih škola i pravaca koji u središte zanimanja stavljaju političnost i etičnost predmeta vlastita istraživanja. Rodni studiji, queer studiji, kulturalni studiji, kulturalni materijalizam, novi historizam, postmodernistička naratologija i dr. bave se upravo analizom političkih strategija i njihovih etičkih učinaka u različitim područjima ljudskog djelovanja. Sam je Derrida svoj rad u devedesetima gotovo u cijelosti posvetio etičkim/ političkim pitanjima. Najoštriji je protivnik Derridaove etike/politike dekonstrukcije sve do danas Žižek koji njezinu pogubnu utjecaju suprotstavlja lakanovsku etiku/politiku. U međuvremenu se javljaju i drugi autori, poput talijanskog filozofa Agambena, koji na određeni način nastavljaju pisati na tragu Foucaultovih kasnijih radova o biopolitici. U ovom tekstu, dakako, u obzir će se uzeti samo jedan odsječak toga višeglasnog teorijskog razgovora.

4 Usp. npr. studije: P. Shaw, The Sublime, New York 2006, F. Ferguson, Solitude and Sublime, New York - London 1992 i D. Ellison, Ethics and Aesthetics in European Modernist Literature. From the Sublime to the Uncanny, Cambridge - New York 2001. 
filozofije, teologije ili estetike, nego su također dio jezika psihoanalize, a psihoanalitička misao danas, čini se više nego ikad, utječe na otvorene žučne, već spomenute, političke, etičke, pa i estetičke teorijske debate. U njima su teme poput apokalipse, kraja povijesti, iscrpljenosti vremena i slično česte kao uostalom i u lirici Rešickog.

Razložno je, zbog prirode rasprave, ovdje uvesti vrlo kratku obilaznicu. Na prijelazu iz osamnaestog u devetnaesto stoljeće, da spomenem samo jedan primjer, u knjizi Genij kršćanstva, francuski esejist, diplomat i novelist François René de Chateaubriand govori o svojem dobu kao o bolesnom i ispraznom. Pojava u to vrijeme takozvane gotičke književnosti - koja ,izdiže ogavne utvare potpune društvene dezintegracije pri čemu vrlina mjesto ustupa mani, razum žudnji, zakon tiraniji" ${ }^{5}$ - nije ništa drugo doli reakcija na ozračje posvemašnje otuđenosti uzgojeno snažnim ekonomskim i znanstvenim napretkom. Europski književni romantizam neodvojiv je tako od spomenutih osjećaja potaknutih, barem jednim dijelom, i događanjima oko Francuske revolucije. „Približno svi vodeći romantičarski pisci diljem Europe počinjali su kao društveni ili politički reformatori; svi oni bili su virtualno nadahnuti prvom fazom Francuske revolucije" . Miris kraja svijeta, sukladno etimologiji pojma apokalipse, otkrio je perspektivu za apsolutno novi početak. Na toj epohalnoj prijelomnici pjesnik je oblikovan kao prokleti svetac, suludi prorok ili neshvaćeni Mesija. Ovdje bih se mogao pozvati na cijeli niz primjera poput ode Pjesnik (Le Poète) iz 1824. Victora Hugoa u kojoj se opisuje pjesnikov svetački put. On polazi od patnje zemaljskih boli pa ide do uzvišenog sjedinjenja s misterijem božanske kreativnosti, a na svom putu razgovara s muzama, prorocima i samim Isusom Kristom. Percy Bysshe Shelley u tekstu Obrana pjesništva (A Defence of Poetry) iz 1819. na popis pjesnika uvrštava i samog Mojsija kao oličenje ljudskog genija posvećenog ispunjenju božanske misije. U hrvatskoj književnosti Silvije Strahimir Kranjčević - gestom zakašnjela romantičara, kako je to jednom prilikom ustvrdio Miroslav Krleža (1963) - oblikuje figuru pjesnika upravo oko likova Mojsija (pjesma

5 F. Botting, Gothic, Abingdon - New York 1996, str. 5.

6 M. Ferber, Romanticism, Oxford - New York 2010, str. 31. Usporedi također A. Day, Romanticism, London - New York 1996 i M. Janion, Romantizam, revolucija, marksizam, prev. S. Subotin, Beograd 1976. 
Mojsije) i Isusa Krista (pjesma Eli! Eli! Lama Azavtani?!). Sukladno tome Kranjčević svijet prikazuje kao apokaliptično revolucionarno doba (pjesma Resurrectio) u kojemu Isus Krist silazi s križa ne bi li za trenutak pružio svijetu i ljudima mogućnost općeg prevrata?

$\mathrm{U}$ svjetlu spomenutog povezivanja vizija o iscrpljenosti vremena i dobu revolucije te o Umjetničkom-Geniju-Proroku-Patniku, lirika se Rešickog dade čitati kao neoromantičarska. Najprije, u tom smislu, želim istaknuti da je njegov lirski opus premrežen motivima čavala, badema (ili lješnjaka) te školjaka. U zapadnoj kulturnoj tradiciji sva su tri spomenuta motiva povezana s likom Isusa Krista. Čavli su simbol muke Isusa Krista, bademi, zbog bademastog oblika aure, njegove duhovnosti, a školjka je pak hodočasnički znamen koji je Mesija nosio uza se ${ }^{8}$. Kada se u lirici Rešickog na Isusa Krista referira izravno, uvijek se to čini tako da se tradicionalno shvaćanje njegova djela ili nauka, najblaže rečeno, preosmišljava u novom kontekstu. Evo stihova koji to ilustriraju: ,jebala sam se / u toplim krevetima svojih prijateljica (...) radila sam to na snijegu / brišući ti uplakane oči svojom menstrualnom / maramicom / na koju mi se potpisao isus / odmah poslije koncerta"9. Već je u kritici primijećeno da su lirski svjetovi Rešickog stilizirani kao svojevrsno apokaliptično doba. Premda u naslovu zbirke Ezekijeleva kola (1999) izravno upućuje na biblijskog proroka Ezekijela koji je imao apokaliptičnu viziju, Rešicki, ponajprije, u svom lirskom opusu vrijeme suvremena svijeta prikazuje kao neodređenu prijelomnicu kraja i početka vremena, izvanredno stanje u kojem se sve spaja sa svime u točki potpune nedjeljivosti. To, dakle, nije ni kružno vrijeme mitske predpovijesti u kojem se subjekt vječno obnavlja, a nije ni nepovratno vrijeme modernoga čovjeka obilježeno njegovim nužnim propadanjem. Riječ je o nekakvu vremenu u kojem se sve suprotnosti sjedinjuju: o istodobnoj privrženosti osjećajima vječnosti i konačnosti,

7 Bogata je recentna literatura o problemu autorstva, njegovu formiranju u epohi romantizma i povezivanju s idejama Genija, Proroka, Mesije ili božanskog nadahnuća. Spomenut ću ovdje samo tri knjige: The Theory of Inspiration Timothya Clarka, Poetry and Prophecy urednika Jamesa L. Kugela i Autorship: From Plato to Postmodernism: A Reader urednika Seána Burkea. Vidi popis literature.

8 Usp. J. Hall, Rječnik tema i simbola u umjetnosti, Zagreb 1991.

9 D. Rešicki, Die die my darling, Zagreb 1990, str. 48. 
propasti i nove zore, o zatvorenosti „kružnog toka između prošlosti i budućnosti"10. Ukopčavanje subjekta u zastrašujući vrtlog otvoren kratkim spojem prošlosti i budućnosti, a o tome Žižek govori u kontekstu rasprave o valjanom etičko-političkom činu, upravo je identično preuzimanju (na sebe, kao usud) sulude i nemislive jednakosti krajnosti, što je temeljna struktura djelovanja lirskih junaka u lirici Rešickog.

Danas, pak, tu jednakost krajnosti najizravnije zagovara ,,apokaliptični «kršćanski materijalizam»" 11 koji, u hegelovskoj maniri, konkretno združuje s univerzalnim, Isusa Krista s Bogom, etiku s politikom, ali tako da se njihovo jedinstvo shvaća kao proizvod nužne negacije ili pukotine jedinstva ${ }^{12}$. Jedinstvo Boga i čovjeka, utjelovljeno u Isusu Kristu, nije konačno usklađivanje savršenstva i kaosa, nego otvaranje kaotičnog bezdana u samom savršenstvu. To, s druge strane, ukazuje na činjenicu da sublimno (duhovno), kada se pojavljuje, nužno ulazi u odnos sa zazornim (materijalnim objektima): dimenzija beskonačnosti ne otvara se izvan, nego unutar trošivog i konačnog svijeta. U tom smislu transcendencija nije neka nepojmljiva onostranost, nego se, takoreći, onostranost pojavljuje u središtu ovostranosti kao distorzija, izobličenje poretka stvari. Subjekt valjanog etičko-političkog čina, prema Žižeku, djeluje poput Isusa Krista koji utjelovljuje upravo takvu desublimiranu, zazornu sublimnost, objavu nemogućeg (iščašenja) unutar poretka mogućeg ${ }^{13}$. Isus Krist, dakle, otvara dimenziju proturječne apokaliptične vremenitosti. On zna da je u budućnosti katastrofa neizbježna, ali (ovog

10 S. Žižek, B. Gunjević, Bog na mukama. Obrati apokalipse, prev. R. Karlović, Zagreb 2008, str. 37.

11 Ibidem, str. 36.

12 Konkretna univerzalnost pojam je koji objašnjava mogućnost univerzalnog da prijeđe u partikularno i tako u potpunosti preuzme kontigentnost singularnih pojava realnosti, ali i obrnuto, sposobnost konkretnog da u realnosti izbije kao univerzalno koje prekoračuje njezine važeće zadane okvire. Pravi je paradoks Hegelove ideje Univerzalnog u tome što ,ono nije neutralni okvir mnogobrojnih partikularnih sadržaja, nego je inherentno podvajajući, razdire vlastite partikularne sadržaje: Univerzalno sebe uvijek iznosi pod krinkom nekog partikularnog sadržaja koji tvrdi da ga izravno utjelovljuje izuzimajući sve druge sadržaje kao isključivo partikularne". S. Žižek, The Ticklish Subject. The Absent Centre of Political Ontology, London - New York 1999, str. 101 .

13 O Žižekovu shvaćanju valjanog etičko-političkog čina opširnije sam pisao u studiji Ljubi Žižeka svoga. Vidi u popisu literature. 
časa) čini sve da promijeni usud njezinih pogubnih posljedica. Na taj način, djelujući (u prošlosti nedošle budućnosti) kao da je budućnost već tu, poredak stvari uzdrmava iz temelja ${ }^{14}$.

Valja svakako imati na umu da je takvom tipu vremenskog paradoska bio odan otac suvremenog pjesništva Charles Baudelaire koji je sebe smatrao izvornim romantičarem ${ }^{15}$. Naime, u članku Slikar modernog života, pišući o slikama, crtežima i ilustracijama svog sunarodnjaka Constantina Guysa, Baudelaire zastupa tezu da je tu ,riječ o strahu da se ništa ne događa dovoljno brzo, o strahu da se dopušta da fantom pobjegne prije negoli se iz njega sinteza izluči i zabilježi"16. Bježeći fantom, o kome govori Baudelaire, na Guysovim je radovima predočen kao život koji se utapa u neko sablasno, uznemirujuće i bolećivo raspadanje. Ono što je prikazano, kao da se već u samom prikazu rastače i nestaje. Ta proturječna istodobnost običnog i neobičnog, jasnog i nejasnog, poznatog i čudnog, vidljivog i nevidljivog pobuđuje iskustvo zazornog. Baudelaire tu pledira za shvaćanje moderniteta kao fantomskog doba - više ne prošlosti, još ne budućnosti - a ultimatum da se živi na tom utvarnom raskršću bez osvrtanja unazad i gledanja unaprijed budi osjećaj ontološke neodlučivosti karakteristične za modernog čovjeka i, napose, modernog umjetnika. Riječ je, dakle, o zahtjevu za intenzivnim proživljavanjem (političke, etičke i poetičke) trenutnosti koja se opire usustavljivanju i shvaćanju, grubo je odvojena od tradicije, a s napretkom nije povezana, ne brine se ni za povijesne spone, ni za

14 Žižek s tim uspoređuje Lenjinove Aprilske teze iz 1917, program proleterske revolucije koji su osudili svi njegovi najbliži suradnici smatrajući da povijesna nužnost nalaže nepreskakanje takta društvenog razvitka. Iz feudalizma, prema njihovu mišljenju, nije moguće prijeći u socijalizam, nego se prvo treba izboriti za buržoasku revoluciju. Lenjin je ipak ustrajao, a Žižek smatra da je djelovao u skladu s opisanom čudovišnom vremenitošću. Nedjelovanje u sadašnjosti on je, naime, vidio iz budućnosti kao fatalnu pogrešku i djelovao je. Lenjin je, dakle, anticipirao katastrofu u budućnosti zbog nedjelovanja u sadašnjosti i djelovao je tako da se to u sadašnjosti činilo kao ludilo, a u budućnosti kao jedini mogući izbor. Na taj je način iz temelja promijenio svijet.

15 Usp. M. Calinescu, Lica moderniteta: avangarda, dekadencija, kič, prev. G. Slabinac, Zagreb 1988, str. 53.

${ }^{16}$ Ch. Baudelaire, The Painter of Modern life, u: Selected Writings on Art and Literature, prev. P. E. Charvet, Harmondsworth 1992, s. 408. Navod prema J. Jervis, Uncanny Presences, u: Uncanny Modernity, ur. J. Collins i J. Jervis, New York 2008, str. 10 . 
nadolazeće vrijeme. Slijeđenje takve radikalne časovitosti jamči pristizanje u mjesto uključene iskorijenjenosti. Na tom se bezvremenom mjestu subjekt pojavljuje kao zazorno čudovište. Zbog toga Žižek Isusa Krista proglašava monstruoznim subjektom etičko-političkog čina jer se u vremensko-prostornom kontinuumu židovske vjere pojavljuje kao dijabolično zlo. Djelovanje Isusa Krista nema za posljedicu pomirenje ljubavi i mržnje, etike i politike, Boga i čovjeka, nego pokazuje da su ljubav, etika i Bog nužno, iznutra, izobličeni mržnjom, politikom i čovječnošću. U trenutku raspeća, a to je zapravo trenutak apokalipse u kojem umire sam Bog, ,jaz koji dijeli Boga od čovjeka biva razmješten u samoga Boga, kao jaz koji dijeli Krista od Boga Oca; pritom je pravi dijalektički trik u tom da me, na koncu, s Bogom sjedinjuje ono svojstvo koje me naizgled dijelilo od Boga"17. Baudelaireov moderni umjetnik dvojnik je razapetog Isusa Krista - bezvremeni Genij čija se bezvremenost i genijalnost mogu pojaviti samo kao trošivo, materijalno tijelo.

U lirici Rešickog oživljuje se, na određeni način, apokaliptično (bodlerovsko, kršćansko materijalističko) shvaćanje vremena. U njoj se na najuvrnutiji način susreću zapleti evanđelja i sapunica, filmovi znanstvene fantastike i nacionalni mitovi, junaci iz stripova i kršćanski sveci. Jezik poezije Rešickog kao da oblikuje vremenoprostor bez podjela i puknuća, neko neodređeno tamo gdje „crni prezervativ kao kos u snježnoj zimskoj šumi / putuje u anus anđela", da navedem samo jedan drastičan primjer ${ }^{18}$. Krešimir Bagić, naime, tvrdi da Rešicki ,ima potrebu za građenjem takvoga lirskog svijeta u kojemu će se uvijek moći iznova počinjati”19. Vladimir Biti, pak, smatra da u „svijetu umrle utopije" u zbirci Die die my darling ,jedino što životu daje kakvo-takvo opravdanje jest tvrda spremnost za njegovu bezizlaznost" ${ }^{20}$. Usudio bih se, dakle, ustvrditi da u suvremenoj hrvatskoj poeziji Rešicki oblikuje onaj tip svjetonazora koji Žižek, u polju suvremene filozofije, pridružuje

17 S. Žižek, B. Gunjević, op. cit., str. 158.

18 D. Rešicki, Die die my darling, op. cit., str. 14.

19 K. Bagić, Tema praznine u hrvatskome pjesništvu druge polovice 20. stoljeća, u: idem, Treba li pisati kako dobri pisci pišu, Zagreb 2004, str. 84.

20 V. Biti, Uskrsnuće 'mrtve utopije’ lirske tradicije, „Poezija” 2005, br. 1-2, str. 90 . 
apokaliptičnom kršćanskom materijalizmu. U romantičarskoj, doslovno gotičkoj maniri, Rešicki prikazuje civilizaciju na svom kraju. Paradigmatična je pjesma Klon 8 iz knjige Ezekijeleva kola. Evo samo nekih stihova: „Dolazi doba velike berbe / operimo stare bačve. (...) // Pogledajmo češće na sat / jer Tantal već godinama potajno / i jede i pije (...) // Kad zaspi / i napit i sit/ valjajući se u svojoj bljuvotini / prorok će promoliti glavu / kroz ranu / koju je na ruci učinio čavao od devet inča" ${ }^{21}$. Lirski subjekt i drugi protagonisti lirskih svjetova Rešickog oblikovani su kao prokleti otpadnici čije je ludilo sveto ${ }^{22}$. Lik Isusa Krista, vidjeli smo i u maloprije navedenim stihovima, tu ima posebno mjesto. To nije Mesija, kao što sam već istaknuo, koji se za nas žrtvuje ili je tek utjelovljenje Boga na zemlji. To je čudovišni Mesija - kako ga u više navrata naziva Žižek ${ }^{23}$ - upravo zato što ukazuje na ograničenje transcendentalnog načela. Tvrdim da ta strategija ima veze s lirskim strategijama Rešickog.

Žižek, naime, kao uostalom i Rešicki, smatra da mi danas živimo u vremenu označenom signalima apokalipse. Globalni kapitalizam na početku 21. stoljeća proizvodi svijet visokog rizika čijemu opstanku prijete ekološke, medicinske, tehnološke, evolucionističke i druge katastrofe. To se događa uslijed specifične pojave koju Žižek katkad imenuje ,postmodernističkom refleksivnošću" "24. Kada se, dakle, danas javi kakva realna prijetnja životu, pozivaju se u pomoć visoka znanost i tehnologija koje privremeno otklanjaju opasnost, ali na duge staze proizvode veliku i nepopravljivu štetu. Žižek također smatra da naše doba obilježava perverzna i opasna povezanost kapitala i mazohističkog užitka koju nitko više ne može prekinuti. To se, primjerice, ogleda u bjesomučnim kupovinama na rasprodajama gdje nas pod krinkom štednje kapitalizam još snažnije veže za svoju logiku potrošnje. Zbog sveopće relativizacije vrijednosti za današnje stanje svijeta nitko više nije odgovoran. Mjesto je političkog i etičkog (a valjda i estetičkog)

21 D. Rešicki, Ezekijelova kola, Zagreb 1999, str. 73.

22 V. Biti, op. cit., str. 89-90.

23 Usp. S. Žižek, The Fragile Absolute. Or Why Is the Christian Legacy Worth Fighting For?, London - New York 2000; S. Žižek, O vjerovanju. Nemilosrdna ljubav, prev. M. Miladinov, Zagreb 2005; S. Žižek, B. Gunjević, op. cit.; S. Žižek, J. Milbank, The Monstrosity of Christ, Paradox or Dialectic?, Cambridge - London 2009.

24 S. Žižek, The Ticklish Subject..., op. cit., str. 341-347. 
autoriteta ispražnjeno. Ono što je, u tom smislu, Žižeku važno nije tek skicirati zeitgeist, nego iznjedriti rješenje. On ga nudi pod egidom apokaliptičnog kršćanskog materijalizma personificiranog likom Isusa Krista. Samo „Bog koji trpi može nas spasiti”25, samo „čudovišni Krist" ${ }^{26}$ može poslužiti kao smjerokaz za izlazak iz slijepe ulice liberalne kapitalističke upetljanosti u zloslutno i opsceno kruženje kapitala što nas, očigledno, odvodi u propast.

Pokušat ću to ukratko pojasniti, iako se Žižek poziva na mnogobrojna složena filozofska i teološka čitanja koja gusto prepleće s lakanovskom psihoanalizom. Svako rješenje krizne situacije koje se poziva na neko univerzalno načelo poput znanosti, tehnologije, Boga ili novca samo održava ili čak pogoršava postojeće neizdrživo stanje. Sudbina Isusa Krista važna je zbog toga što ukazuje na jedan oblik djelovanja koji se ne poziva na moć odredbenog transcendentalnog zakona. U Isusu Kristu, tvrdi Žižek, dolazi do potpunog preklapanja općeg i pojedinačnog, a to isključuje naknadno oslanjanje na kakav neupitni ili izvansvjetovni autoritet. Mesijin posljednji vapaj „Oče, oče, zašto si me ostavio?” svjedoči, prema Žižekovim riječima, o ateističnosti samog Boga ${ }^{27}$. U tom času Bog ne vjeruje u Sebe: vlastitu svemogućnost dovodi u pitanje, shvaća zapravo da nije ništa drugo doli običan čovjek. Monstruoznost Isusa Krista upravo je u tome. On pokazuje da ona dimenzija koju povezujemo sa sublimnim (Bog) nužno jest neko zazorno (čovjek, otpadnik). Isus Krist, tako, iznosi na vidjelo da se ono što se čini nemogućim ipak $\operatorname{događa}^{28}$. To nije promjena u okviru Zakona - zakona židovske vjere, zakona kapitala - nego promjena samog Zakona. Prema Žižeku Isus Krist je figura koja ukazuje na mogućnost pojave nemogućeg - ljubavi iz mržnje, dobra iz zla - drugim riječima pojave „bezdane neumjerene geste koja više ne može biti uklopljena u «uobičajeno ljudsko promišljanje»" "29. Tome je, u Žižekovoj interpretaciji, srodan valjani, bezumni, revolucionarni etičko-politički čin. U takvom činu subjekt se ne žrtvuje zbog neke više stvari. U njemu subjekt žrtvuje samo

25 S. Žižek, B. Gunjević, op. cit., str. 133-170.

26 S. Žižek, J. Milbank, op. cit.

${ }^{27}$ Usp. S. Žižek, B. Gunjević, op. cit., str. 166.

${ }_{28}$ Usp. idem, O vjerovanju ..., op. cit., str. 100.

${ }^{29}$ Idem, The Fragile Absolute..., op. cit., str.155. 
žrtvovanje, samu tu višu stvar. Zato valjani etičko-politički čin uvijek izgleda besmislen, ali se retroaktivno pokazuje kao nužnost. Prelaskom uzvišena Boga u unižena Isusa Krista događa se kratki spoj koji djeluje kao trenutna obustava sustava. Isus Krist je tako redefinirao ono što se do tada smatralo mogućim.

Takav čudovišni Isus Krist - Božji otpadak, tijelo koje pati ne zato što je ljudski konačno, nego zato što se u njemu Bog suočava s činjenicom da je bijedan ljudski stvor - jedna je od središnjih figura pjesništva Rešickog. Upravo su europski romantičari, ali i hrvatski ako se u romantizam može ubrojiti pjesništvo Kranjčevića, njegovali privrženost figuri Isusa Krista i povezivali su je s hegelovskom idejom materijalizacije apsoluta na sličan način kako to danas čini Žižek u okviru projekata apokaliptičnog kršćanskog materijalizma i ateističke materijalističke etike $^{30}$. Ono što Isusa Krista čini jedinstvenim, 1838. piše američki romantičar Ralph Waldo Emerson, nije to što on sam postaje Bog, nego što Bog sam vidi sebe kako se utjelovljuje u čovjeku ${ }^{31}$. Transcendencija se desublimira tako da od onostranosti ne ostaje ništa osim nekakvog zazornog materijalnog viška.

Upravo u tome vidim radikalnost lirske poetike Rešickog. Tu nije u tolikoj mjeri važno postmodernističko pastiširanje kristoloških motiva. Tema materijalizacije božanskog principa zapravo je simptom formalnog odnosa Rešickog prema instituciji književnosti i kulture (kao božanskih niša u zemaljskom kalu). Kao što u Žižekovoj interpretaciji u tijelu Isusa Krista Bog više ne vjeruje u sebe, tako u lirici Rešickog lirika više ne vjeruje u sebe. Napose u knjizi Die die my darling uzvišeno i uniženo spajaju se na čudovišan način, drugim riječima visoka kultura pada u supkulturu i više se od nje ne može razlikovati. U lirici Rešickog visoka kultura sebe vidi kao obično supkulturno smeće. Kao što je u Isusu Kristu Bog doslovno čovjek, u lirici Rešickog visoka je kultura doslovno supkultura. Ne postoji tu više neka onostrana duhovnost kulture na koju se možemo pozvati. Lirika je to koja žrtvuje samu sebe i pokazuje kako ne postoji neka njezina nedokučiva sveznajuća drugost. Sve uzvišeno u lirici je u njoj samoj: u materiji jezičnog sudaranja, u isprepletanju označiteljskih

30 Usp. S. Žižek, J. Milbank, op. cit.

31 Usp. M. Ferber, op. cit., str. 64. 
praksi i naslagivanju kulturnih kodova. Lirika se besmisleno odriče sebe tako što ostaje ono što je oduvijek bila - čista materijalna konvencija bez transcendencije.

U tom smislu, u lirici Rešickog, i shvaćanje romantičarske figure Autora Genija doživljava znatnu preinaku. Naime, u pjesništvu hrvatskih pjesnika koji su se javili početkom sedamdesetih godina dvadesetog stoljeća (Milorad Stojević, Ivan Rogić-Nehajev, Darko Kolibaš i drugi) Autor Genij detroniziran je prema bartovskom scenariju, smaknućem njegovih božanskih moći. Prema tim pjesnicima, pjesnik nema nadležnost nad smislom pjesme jer je njegov iskaz unaprijed uhvaćen u mrežu jezičnih kodova i konvencija kojima ne može ovladati. Zaoštren je to antiintencionalistički i antiteološki stav kojim se namjera autora, kao jedino moguće ishodište značenja lirike, odbacuje. Ta strategija, međutim, na ispražnjeno prijestolje umjetničkog smisla vraća Autora Znalca koji je ovladao svim kanonskim vrijednostima pa ih jedino on ima pravo porušiti. Opravdano je reći da je Autora Genija u sedamdesetima s trona izgurao Autor Znalac, a ta je promjena kozmetičke naravi i nije bitno pridonijela drukčijem shvaćanju autorstva i institucije književnosti. U lirici Rešickog, pak, Autor Genij nije otpisan iz književne komunikacije, nego je u nju iznova upisan na drukčiji način.

Stilizacijom lirskog subjekta kao (urbanog) nomada, središnja se iskazna funkcija lirskog teksta na neizravan način povezuje s romantičarskom idejom vagabunda ili lutalice. Njegov put nije određen ni itinerarijem, ni odredištem, ni mjestom iz kojeg kreće, ni mjestom u koje namjerava stići. No, za razliku od postmodernističkog vagabunda, utjelovljenog u figuri turista, čiji je egzistencijalni model „trajni odmor”, „fizička odvojenost, duhovna udaljenost" ${ }^{32}$, zapravo bezinteresno sudjelovanje bez pripadanja, lutalica u lirici Rešickog onome od čega je odvojen pripada i više negoli je to moguće. Njega tako ne obilježava manjak, nego višak sudjelovanja. Vagabund je u lirici Rešickog neka prekomjernost koju nije moguće obuzdati interpretacijom. On utjelovljuje stalnu promjenu perspektiva (spoznajnih, političkih, poetičkih i slično), prelaženje ontoloških razina (roda, živog i neživog i slično) i gutanje predmetne i nematerijalne zbilje. Zbog zatrpanosti svijetom

32 Z. Bauman, Postmodern Ethics, Oxford - Cambridge 1993, str. 243. 
bez ostatka (u njega ulazi sve što vidi, čuje, dotiče i misli) vagabund je krajnje odvojen od svijeta. On u svojoj materijalnoj konkretnosti i partikularnosti označava ograničenje univerzalnosti na isti onaj način na koji u Žižekovoj konceptualizaciji kršćanstva čini Isus Krist. Vagabund usisava apsolutno Sve, ili sve kao Apsolut, ali upravo zbog toga on je mjesto gdje to neko Sve ili Apsolut prelazi u pojedinačnost. Drugim riječima, lirika je Rešickog neka sveopća tekstualnost u kojoj su granice između književnih rodova i kulturnih polja prebrisane, ali je, paradoksalno, upravo zbog toga jedinstvena lirska gesta. Ta lirika kao da parafrazira čuvenu Lacanovu dosjetku - ,imam tri brata Paula, Ernesta i sebe" 33 - govoreći: objedinjujem sve rodove epiku, dramu i sebe. Načelo univerzalnosti u njoj se pojavljuje kao nužno osakaćeno pojedinačnošću.

Nije, stoga, čudno da knjiga Die die my darling - koja je prema tradicionalnom shvaćanju moralnosti krajnje amoralna - završava pjesmom Otići ću u Sečuan da tamo umrem s pandama. Aludirajući na dramu Dobri čovjek iz Sečuana, Rešicki stilizira lik vagabunda tako da ga povezuje s Brechtovim shvaćanjem historijskog materijalizma i, naravno, morala. Taj materijalistički vagabund eskapizam ne doživljava kao priliku za bijeg iz postojećeg sustava, nego kao priliku za radikalnu

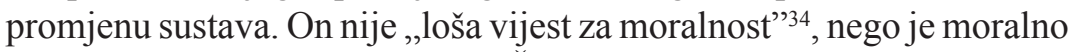
i političko čudovište koje, poput Žižekova čudovišnog Isusa Krista ili zazornog glavnog lika Šen Te Brechtove drame, potpuno mijenja ustaljeno shvaćanje dobra. Lik je vagabunda, u Rešickog, u više navrata, na izravan način povezan s građanskom osobom pisca, a onda i s idejom autorstva. (Na primjer u pjesmi Kažem tebi iz knjige Die die my darling lirski se subjekt autoreferencijalnom gestom obraća Rešickom.) U tom se smislu autorska funkcija u lirici Rešickog može shvatiti kao lutalačka - ideja se autorstva zadržava tako da je se stalno izlaže riziku dezintegracije. Moć se autora ne veliča, niti se odbacuje, nego se promatra kao izvorište za promjenu institucionalnog sustava u kojem djeluje i za promjenu same ideje autorstva. Autor je zamišljen kao vagabund privržen činu lutanja što u osnovi ima cilj promijeniti okolnosti pod

33 J. Lacan, Četiri temeljna pojma psihoanalize, Zagreb 1986, str. 26.

34 Z. Bauman, op. cit., str. 242. 
kojima se luta. Vagabund u lirici Rešickog tako ne žrtvuje sve blagodati građanskog života u ime sentimentalne ideje lutanja, nego žrtvuje i samu ideju lutanja hladno i okrutno pomičući jezične granice.

Potez je to od iznimne političke, etičke i estetičke važnosti. Mi danas ne živimo u vremenu kada je kultura roba, nego kada je sva roba kultura. Mobilni telefon je dizajn, priprema hrane je umjetnost, trošenje novca je nadahnuće. Umjesto slogana sex sales danas vrijedi culture sales. Nije više riječ o tome da su naši duhovni odnosi postvareni, nego se robe i materijalni odnosi pokušavaju oduhoviti. Taj je poganski spiritualizam vidljiv na svakom koraku. Sjaj lažne sublimnosti danas pada na sve oblike kulturnog otpada. Svi odjednom sudjeluju u kulturi: nogometaši, političari, starlete, kapitalisti, i to je ono što je opasno danas. Lirika koja odustaje od svoje uzvišene drugosti i samu sebe srozava u zazornu trošivost, lirika koja pasivno ustrajava na sebi kao zadnjem otpatku možda može prekinuti, barem za tren, opscenu uvezanost kulture i uzvišenosti, a zapravo kulture i globalnog kapitala. Ta nas lirika može naučiti, i zato bi je trebalo uvrstiti u kurikulum književnog, ali i religijskog obrazovanja, da ovo stanje nije konačno, da ako i postoji neka onostranost ona nije utješna, milostiva i produhovljena, nego izbija tu među nama kao nemoguć kratak spoj, zlosretno puknuće, katkad i kao užas iza kojega se može nazrijeti novi svijet.

\section{Literatura}

Bagić K., Tema praznine u hrvatskome pjesništvu druge polovice 20. stoljeća, u: Treba li pisati kako dobri pisci pišu, Zagreb 2004, str. 23-109.

Baudelaire C., The Painter of Modern life, u: Selected Writings on Art and Literature, prev. P. E. Charvet, Harmondsworth 1992.

Bauman Z., Postmodern Ethics, Oxford - Cambridge 1993.

Biti V., Uskrsnuće 'mrtve utopije' lirske tradicije, „Poezija” 2005, br. 1-2, str. 89-90.

Botting F., Gothic, Abingdon - New York 1996.

Burke S., Autorship: from Plato to Postmodernism, Edinburg 1995.

Calinescu M., Lica moderniteta: avangarda, dekadencija, kič, prev. G. Slabinac, Zagreb 1988. 
Clark T., The Theory of Inspiration, Manchester - New York 1997.

Crockett C., A Theology of the Sublime, London - New York 2001.

Day A., Romanticism, London - New York 1996.

De Chateaubriand F. R., Genij kršćanstva, Zagreb 2006 [11802].

Ellison D., Ethics and Aesthetics in European Modernist Literature. From the Sublime to the Uncanny, Cambridge - New York 2001.

Ferber M., Romanticism, Oxford - New York 2010.

Ferguson F., Solitude and Sublime, New York - London 1992.

Hall J., Rječnik tema i simbola u umjetnosti, Zagreb1991.

Hugo V., Izabrani stihovi, Beograd 1985.

Janion M., Romantizam, revolucija, marksizam, prev. S. Subotin, Beograd 1976.

Jervis J., Uncanny Presences, u: Uncanny Modernity, ur. J. Collins, J. Jervis, New York 2008.

Kranjčević S. S., Izabrana djela, Zagreb 1996.

Krleža M., O Kranjčevićevoj lirici, u: Eseji III, Zagreb 1963.

Kugel J. L., Poetry and Prophecy, New York 1990.

Lacan J., Četiri temeljna pojma psihoanalize, Zagreb 1986.

Pavličić P., Mala tipologija moderne hrvatske lirike, Zagreb 2008.

Rem G., Koreografija teksta. Pjesništvo iskustva intermedijalnosti, Zagreb 2003.

Rešicki D., Gnomi, Zagreb 1985.

Rešicki D., Sretne ulice, Osijek 1987.

Rešicki D., Die die my darling, Zagreb 1990.

Rešicki D., Knjiga o anđelima, Zagreb 1997.

Rešicki D., Ezekijelova kola, Zagreb 1999.

Rešicki D., Aritmija, Zagreb 2005.

Shelley P. B., Obrana poezije i slobode, Beograd 1990 [11819].

Shaw P., The Sublime, New York 2006.

Vuković T., Ljubi Žižeka svoga, Zagreb 2009.

Žižek S., The Ticklish Subject. The Absent Centre of Political Ontology, London - New York 1999.

Žižek S., The Fragile Absolute. Or Why Is the Christian Legacy Worth Fighting For?, London - New York 2000.

Žižek S., O vjerovanju. Nemilosrdna ljubav, prev. M. Miladinov, Zagreb 2005.

Žižek S., Gunjević B., Bog na mukama. Obrati apokalipse, prev. R. Karlović, Zagreb 2008.

Žižek S., Milbank J., The Monstrosity of Christ. Paradox or Dialectic?, Cambridge - London 2009. 